\title{
Kierkegaard, Luther, troen, tilegnelsen og samvittigheden
}

\author{
Ph.d., sogneprest \\ Pia Søltoft
}

\begin{abstract}
This article first deals with the relation between reason and faith, arguing that Søren Kierkegaard viewed Martin Luther as a rather "undialectical" thinker in his understanding of faith, since Luther, according to Kierkegaard, failed to acknowledge that reason and a possible outrage is the first step of faith, to be followed by a passionate devotion that Kierkegaard calls a "second immediacy", which is another word for faith. Secondly, the article addresses Kierkegaard's more positive view of Luther with regard to the appropriation of Christianity by the individual. Thirdly, Kierkegaard's, Luther's, Nietzsche's and Hannah Arendt's views on the consciousness are discussed.
\end{abstract}

Keywords: Faith, reason - paradox - immediacy - passion - reflection - appropriation - consciousness - Kierkegaard - Luther - Nietzsche Hannah Ahrendt.

Det er især forholdet mellem fornuften og troen, der både har interesseret og irriteret Kierkegaard i forbindelse med hans læsning af Luther. Mens Luthers syn på det enkelte menneskes personlige tilegnelse og hans opfattelse af samvittighedens rolle vurderes udelt positivt. Kierkegaards kritik af Luther og særligt af den senere protestantisme har primært at gøre med forholdet mellem fornuft og tro og med fremstillingen af troen som en ren gave.

I det følgende vil jeg begynde med Kierkegaards tvetydige syn på Luthers opfattelse af troen. Kierkegaard kan simpelthen ikke finde ud af, hvad Luther mener og ender derfor med at kalde ham u-dialektisk, når det kommer til en beskrivelse af troen.

Dernæst vil jeg se nærmere på den positive måde, hvorpå Luthers syn på det enkelte menneskes personlig tilegnelse af troen og hans syn på samvittigheden har præget Kierkegaard og mange andre siden hen, hvorfor også Friedrich Nietzsche og Hannah Ahrendt vil komme til orde i artiklens afslutning.

Dispositionen for denne artikel er derfor som følger: 1. Fornuften og troen 2. Tilegnelsen - pro me. 3. Samvittigheden. 4. Den spidsfindige samvittighed. 5. Den selvopfundne samvittighed. 6. Det Sædelige. 7. Den ængstede samvittighed. 


\section{Fornuften og troen}

Kierkegaard sætter Luther højt. Han er særligt optaget af Luthers prædikener og i en periode læser han dagligt én af disse højt for sig selv hver morgen: "Hvilken Trøst at læse Luther. Det er dog en Mand der kan holde ud med En, og prædike En længere ud, istedetfor at prædike En tilbage" (SKS 20, 315), skriver Kierkegaard i en journaloptegnelse fra 1848. Og i samme journal lyder det: "Jeg har i dag læst Luthers Prædiken efter Tour, den var Evangeliet om de 10 Spedalske. O, Luther er dog Mesteren for os Alle!" (SKS 20, 357).

Men Kierkegaard er alligevel ikke udelt positiv over for Luther. Når det kommer til forholdet mellem fornuften og troen, mener han, at Luther er alt for uklar i sin beskrivelse: "Ofte nok har jeg paaviist hele den moderne Philosophies Confusion betræffende Troen. Men selv i Luthers fremstilling er der dog en Grund-Uklarhed over, hvad han forstår ved Tro" (SKS 20,374), siger Kierkegaard i en journaloptegnelse stadig fra 1848.

Det bærende spørgsmål for Kierkegaard er, hvilket forhold, der opstår mellem fornuften og troen, samt hvorvidt troen så at sige afliver fornuften så denne går helt til grunde. For Kierkegaard udgør troen som bekendt et spring, der så at sige korsfæster fornuften. Troen er paradoksal, absurd og dog det sikreste af alt. Ikke sådan forstået, at der er tale om obskurantisme eller mysticisme, men rettere således at Kierkegaard placerer troen i en sfære for sig. Troen er ikke fornuftens modsætning, men den forholder sig til noget, som fornuften ikke kan begribe.

I bogen Philosophiske Smuler anfører den pseudonyme forfatter Johannes Climacus, at lidenskaben potenseres når et menneske forsøger at forholde sig til noget, det ikke kan tænke eller begribe med sin forstand. Når guden i Philosophiske Smuler betegnes som et paradoks, er der tale om et paradoks for forstanden - ikke for den lidenskab, som troen deler med kærligheden.

Når forstanden støder sammen med paradokset er der for Climacus at se to muligheder. Enten giver forstanden op og så har vi forargelsen, der modsætter sig troen. Men forargelsen er nødvendig, for det betyder, at man tager troens absurditet alvorligt. Forargelsen skal så at sige besværliggøre vejen til troen, så den ikke bare bliver umiddelbar hengivelse uden forudgående refleksion. Undlader vores fornuft at tage kampen op mod paradokset tror vi ikke, ifølge Climacus, men indtager blot en lidenskabsløs indifferentisme, som vi fejlagtigt kalder tro.

Giver fornuften sig derimod hen, hvilket ikke betyder, at den opgiver sig selv, men at den giver plads for, at forstanden ikke behøver at 
kunne begribe alting, så har vi troen: "Dersom Paradoxet og Forstanden støde sammen i den fælleds Forstaaelse af deres Forskjellighed, da er Sammenstødet Lykkeligt som Elskovens Forstaaelse (SKS 4, 252).

Man kan naturligvis ikke bevise, at guden eksisterer som en bevidsthedsuafhængig virkelighed, en metafysisk væren, hvorfor Climacus ikke er sen til at gøre op med de klassiske gudsbeviser. Men man kan erfare guden som en grænse: et "hertil og ikke længere" for forstanden. Støder forstanden sig på paradokset, har vi som vist forargelsen. Giver forstanden sig hen, har vi troen. Forholder den sig slet ikke, indtræder apatien og trøstesløsheden. Derfor "skal man ikke tænke ilde om Paradoxet; thi Paradoxet er Tankens Lidenskab, og den Tænker, som er uden Paradoxet, han er ligesom den Elsker der er uden Lidenskab: en Maadelig Patron" (SKS 4, 242).

I Den store Galaterbrevskommentar 1531/35 giver Luther følgende sammenfatning af hele trosbekendelsens indhold, der netop også betoner det paradoksale, ja, det absurde ved troen: En sammenfatning, hvori han netop som siden Kierkegaard betoner, at troens indhold er uforklarligt og uforståeligt for fornuften:

Når Gud tilkendegiver troens artikler, meddeler han således altid noget, der er helt umuligt og absurd, om man vil følge fornuftens skøn. Således forekommer der bestemt fornuften latterligt og meningsløst, at Kristi legeme og blod tilbydes os i nadveren, at dåben er et bad til genfødelse og fornyelse i Helligånden, at døde står op på den yderste dag, at Kristus, Guds søn, undfanges og bæres i en jomfrus moderskød, at han fødes og må lide uværdig død på et kors, at han opvækkes og nu sidder ved Faderens højre hånd og har magt over himmel og jord [...] For den fatter ikke, at det er den højeste gudsdyrkelse at høre Guds røst og at tro. ${ }^{1}$

Men på trods af, eller måske rettere som følge af, denne overensstemmelse i synet på forholdet mellem troen og fornuften mellem Luther og Kierkegaard, så mener Kierkegaard alligevel, at Luther fejlagtigt opfatter troen som en umiddelbar hengivelse og taler derfor om, at "selv i Luthers Fremstilling er der dog en Grund-Uklarhed over, hvad han forstaaer ved Tro". Kierkegaard mener ikke, at troen blot er en umiddelbar hvilen i tillid til en højere magt. Men troen er heller ikke en refleksionsbestemmelse. Troen er begge dele, eller rettere, troen kommer efter refleksionen.

Nok må fornuften give op, men det kan den netop kun, fordi troen ikke blot er en tillidsfuld og umiddelbar hvilen i hverdagen, men til-

1. WA 40I, 361, 19-362,13 (oversat fra latin af Anna Vind). 
lige en evig fordring om, at man tror på trods af fornuften, på trods at det paradoks, som det er, at den evige Gud er blevet menneske på et givent tidspunkt $\mathrm{i}$ historien. For Kierkegaard betyder ordene: "Du skal tro!", som han gentager både i de opbyggelige taler, i Kjerligheden Gjerninger, i Indøvelse i kristendom og under kirkekampen, at et menneske skal ville trodse fornuften og give sig troen i vold.

For Kierkegaard er troen således ikke umiddelbar, den kommer ikke blot af sig selv af det der høres, fides ex audito, men indbærer, at den, der lytter, forstår det han eller hun hører som en fordring om at trodse fornuften. Til Luther stiller Kierkegaard derfor spørgsmålet: "Er Tro det Umiddelbare, en Vitalitet, en vis genial Vedholden ved dette Liv saa man ikke slipper Haabet og Tilliden [...] eller er det en Reflexions-Bestemmelse" (SKS 20,374). Kierkegaard mener som vist selv, at troen først indfinder sig efter at fornuften har givet op, hvorfor troen indeholder et element af negativ refleksion over fornuftens utilstrækkelighed, der fører til dét, han ofte kalder "Den anden Umiddelbarhed". Det er denne dialektik mellem troen og fornuften, som Kierkegaard mener, at Luther mangler at indse, og det er derfor, at han kaldes u-dialektisk.

Det betyder dog ikke, at Kierkegaard mener, at man kan valge at tro. Man kan og skal ikke valge at tro, for troen er så paradoksal, at den ikke kan besiddes eller afvises via et fornuftigt valg. Den ligger, som nævnt, i en sfære for sig selv. For Kierkegaard at se, indfinder troen sig først efter den fornuftige refleksionen. Først efter at fornuften har givet op, kan den give sig hen.

Kierkegaard mener, at Luther overser dette aspekt og i stedet gør troen til en ren gave, skænket i umiddelbarheden. Men det må jo så være en gave nogen har, de der tror, og andre ikke har, de der ikke tror. I stedet betoner Kierkegaard: "Du skal troe, saa ethvert Msk. kan troe, hvad enten [han] har denne Genialitet eller ikke" (SKS 20, 375).

Det er dette, Kierkegaard mener med, at Luther synes at gøre troen til en genialitet, en evne, der umiddelbar er nogen forundt, mens andre som følge heraf ikke magter den. Og det er derfor, at han opfatter Luther som u-dialektisk og udbryder: "Luther er noget forvirret: noget dialektisk-forvirret. Og paa dette Punkt er det blandt andet jeg maa, som jeg har gjort det, concentrere al min Styrke; den dialektiske Bestemmelse af Troen" (SKS 20, 373f.).

Kierkegaard mener tillige, at det er denne u-dialektiske opfattelse af troen, der videreføres af den senere protestantisme, og at det er den, der har voldt en række af de problemer, som Kierkegaard selv ser sig som kaldet til at gøre op med. Den 26. januar 1855 skriver han således i Øieblikket: 
O, Luther, Du havde 95 Theses: forfærdeligt! Og dog i dybere Forstand jo flere Theses, jo mindre forfærdeligt. Sagen er langt forfærdeligere: der er kun een Thesis. Det nye Testamentes Christendom er slet ikke til. Her er ikke Noget at reformere; det, det gjælder om, er at bringe Lys i en gjennem Aarhundreder fortsat, af Millioner (uskyldigere eller skyldigt) øvet christelig Criminal-Forbrydelse, hvorved man kløgtigt, under Navn af Christendommens Fuldkommengjørelse, har lidt efter lidt søgt at franarre Gud Christendommen, faaet Christendom til at være lige det Modsatte af, hvad den er i det nye Testamente.

Alligevel vil jeg ikke, som Frederik Stjernfelt i Syv myter om Martin Luther, ende i påstanden om, at Luther sådan set slet ikke har bidraget med noget positivt og derfor i virkeligheden slet ikke burde fejres. ${ }^{2}$ Som jeg indledte med at sige, ser Kierkegaard som oftest meget positivt på Luther og han mener, at Luther særligt på to områder har haft afgørende betydning: Når det gælder det personlige gudsforhold og tilegnelsens betydning, og når det gælder samvittigheden rolle $\mathrm{i}$ menneskelivet.

Luther har præget begge forhold på en måde, så de giver genlyd den dag i dag og det er derfor disse to forhold, jeg i det følgende skal opholde mig ved.

\section{Tilegnelsen - pro me}

I 1848 bliver den da 35-årige Kierkegaard pludselig slået af et teologisk og filosofisk interessesammenfald med den Luther, som han netop har dømt u-dialektisk. I en journaloptegnelse skriver Kierkegaard:

Forunderligt! Den Kategorie: "for Dig” (Subjektiviteten, Inderligheden), hvormed Enten-Eller sluttede (kun den Sandhed, der opbygger, er Sandhed for Dig) er just Luthers. Jeg har aldrig egl. læst noget af Luther. Men nu slår jeg hans Postil op,- straks i Evangeliet paa 1ste

2. Frederik Stjernfelt, Syv Myter om Martin Luther (København: Gyldendal 2017), 161: "Har Luther da slet ikke gjort noget godt? Har han overhovedet ikke bidraget til det moderne, oplyste samfunds goder? Hmm. Hvis bidraget skal være noget, Luther rent faktisk intenderede skulle ske, så tror jeg næsten svaret må være nej. Jeg har mere end vanskeligt ved at få øje på bidrag fra ideer, intentioner og handlinger i Luthers teologi og politik, som man kan gå tilbage og glædes over. Hvis man skal finde noget, må det snarere være kontraintentionelle effekter - altså bivirkninger, som Luther ikke selv tilsigtede." 
Søndag i Advent er det han siger "for Dig", det er derpaa det kommer an (SKS 20, 274).

Kierkegaards syn på det opbyggelige, som bestemt ikke kun har at gøre med de mange taler, man plejer at kalde opbyggelige, men som sådan set udgør fortegnet for hele forfatterskabet, er netop præget af dette "for dig", som han mener, er grundideen i al opbyggelse.

Ordet "opbyggelig" blev især anvendt af pietismen om den religiøse proces, der begyndte i det enkelte menneske, der sad derhjemme og læste i opbyggelige skrifter i stedet for at deltage i den statslige gudstjeneste i kirken. Kierkegaard spiller på denne betydning, når han kalder mange af sine taler opbyggelige. Det er taler, der er skrevet til "Hin enkelte", det vil sige til det menneske, der tager sig tiden til at forstå sig selv i forhold til det han eller hun læser.

I forordet til de fleste opbyggelige taler udtaler Kierkegaard derfor, at han ønsker at talerne "finder hiin Enkelte, som jeg med Glæde og Taknemmelighed kalder min Læser”. Og for at blive Kierkegaards læser, skal man netop ikke interessere sig for Kierkegaard. Man skal ikke nysgerrigt spørge, hvem han egentlig var og hvad han selv mente. I 'En første og sidste Forklaring', der er underskrevet S. Kierkegaard og ender Afsluttende uvidenskabeligt Efterskrift bliver det gjort helt klart, at det ikke handler om Kierkegaard selv eller hans personlige overbevisning:

Mit Facsimile, mit Portrait o.s.v. vilde ligesom det Spørgsmål om jeg gik med Hat eller Kaskjet, kun kunne blive Gjenstand for Deres Opmærksomhed, for hvem det Ligegyldige var blevet vigtigt - maaskee til Vederlag for at det Vigtige var blevet dem ligegyldigt (SKS 7, 570).

Som læser af Kierkegaards skrifter skal man derfor udelukkende være selvoptaget. Man skal være optaget af, hvorledes det man læser har betydning for en selv. I en journaloptegnelse fra 1846 lyder det:

Da er Beleiligheden for min Læser. Da søger han Stilhed, da læser han, ikke for min Skyld, ikke for Verdens Skyld, men for sin egen Skyld, da læser han saaledes, at han ikke søger mit Bekjendtskab men undgaaer det - og da er han min Læser (SKS 20,54f.).

Og ofte fortsætter Kierkegaard endog med at bede sin læser om at læse højt for sig selv, som han senere selv skal læse Luthers prædikener højt om morgenen. I forordet til Tre opbyggelige Taler 1843 beskriver han derfor sin potentielle læser på følgende måde. Denne er: 
hiint velvillige Menneske, der læser høit for sig selv, hvad jeg skriver i Stilhed, der med sin Stemme løser Skrifttegnenes Fortryllelse, med sin Røst kalder frem, hvad de stumme Bogstaver vel ligesom have paa Munden (SKS 5, 63).

At Kierkegaard mener det alvorligt med kravet til læseren om højtlæsning ses endvidere af den måde, hvorpå han henvender sig til os i alle sine opbyggelige taler. Som læser tiltales enhver af os således konsekvent som "m.T.", altså "min Tilhører" eller a.T, "ærede Tilhører".

Kierkegaard spiller på den oprindelige bygningsmetafor, der ligger gemt $\mathrm{i}$ ordet opbyggelig. At opbygge er at bygge en bygning op $\mathrm{i}$ højden fra et fundament. Han overfører denne betydning til at gælde det, det ene menneske kan gøre for det andet: At bygge noget op, der allerede ligger i fundamentet i det andet menneske. Kierkegaards opbyggelige taler skal således få den religiøse trang frem i læseren, der allerede er der, men er blevet fortrængt eller glemt.

Men det allervigtigste kendetegn ved det opbyggelige er, at det er noget, man egentlig gør ved sig selv. Den ene kan kun opbygge den anden, hvis den anden vil lade sig opbygge. Opbyggelse beror således på en åbenhed. En villighed til både at se ind i sig selv, men også en villighed til at ville lade sig lede i den rigtige retning. Den villighed kalder Kierkegaard "tilegnelse" og det er tilegnelsen, der er afgørende for, om man forstår det Kierkegaard, Luther eller Bibelen beskriver.

Tilegnelse forudsætter at man føler sig tiltalt. At man opfatter det man læser, som henvendt til lige præcis én selv. Og det er netop derfor Kierkegaard ansporer til højtlæsning af sine opbyggelige taler. Så de bliver til en samtale, hvor læseren bliver en tilhører, men i virkeligheden taler med sig selv. I Christelige Taler lyder det:

Thi hvad Virkning denne sande Tale skal frembringe, beroer ene paa, hvo Tilhøreren er. Der kan maaskee være Den, hvem denne Tale kunde gjøre saa angest, som han aldrig før havde været; men dette er ikke Talens Skyld, det ligger i Tilhøreren. Der var maaskee Den, som ganske samtykkende sagde Ja og Amen til den, hørte den som den saligste Beroligelse; men dette er ikke Talens Fortjeneste, det ligger i Tilhøreren. Det er ikke Talen, der har forfærdet den Ene, og det er ikke Talen, der har beroliget den Anden; det er den Ene og den Anden, der i Talen har forstaaet sig selv (SKS 10, 210).

Al aktivitet ligger således hos læseren eller rettere lytteren: Den læser, der gør sig til tilhører ved at læse højt. Det er læseren, der lader sig opbygge ved at tilegne sig det læste eller sagte. Det betyder, at alt fokus kommer til at ligge på tilegnelsens moment, på det lille "for Dig", 
som Kierkegaard altså mener, at Luther er foregangsmand for. Som det lyder i forordet til Tre Taler ved tenkte Leiligheder: "Hver gjøre Sit, Læseren altsaa meest. Betydningen ligger i Tilegnelsen. Deraf Bogens glade Hengivelse" (SKS 5, 389).

Pointen i det lille "for Dig" og den tilegnelse, det lægger op til, er netop, at det opbyggelige har at gøre med måden vi forholder os til os selv, til livet og til sandheden på. Der gives ingen objektiv Sandhed med stort "S", som vi som udefrakommende betragtere kan stirre os blinde på eller vedtage i fællesskab. Sandheden er altid en sandhed for dig. Sandheden, den mening og sammenhæng i tilværelsen, vi måske ikke længere spørger til i dag, men som Kierkegaard alligevel mener, ytrer sig som en skjult længsel; den sandhed er kun for hver enkelt af os hver i sær.

Men betyder det så at Kierkegaard - og den Luther han tager til indtægt for det lille "for Dig", er individualismens foregangsmænd, selvcentrethedens første forkæmpere og som sådan rødderne til den selvoptagethed og kasten vrag på medmennesket, som vi er vidne til i dag?

Ofte er netop Luthers syn på samvittigheden blevet fremhævet som dannende baggrunden for, at vi i dag ligger alt vægt på det enkelte individ. Kierkegaard deler Luthers syn på samvittighedens væsentlige rolle, men intet kunne være mere forkert end at forbinde synet på samvittigheden med individualisme og selvoptagethed. Tværtimod.

\section{Samvittigheden}

Hverken Luther eller Kierkegaard ser samvittigheden som et lukket kredsløb, hvor det enkelte menneske i enrum taler med sig selv. Samvittighedens stemme er godt nok subjektiv, fordi vi i samvittigheden konfronteres med vores valg og handlinger og vores eget forhold til disse.

Men samvittigheden er også inter-subjektiv. Samvittigheden udgør et fælles etisk rum, hvor hver enkelt af os tager sig tid til at stiller et spørgsmål som: "Hvad skal jeg gøre?” og siden:” Var det det rigtige, jeg gjorde?". Som oftest hører vi mest til samvittigheden, når den dømmer os. Den dårlige og den ængstede samvittighed, som Luther tit taler om, er langt mere almindelig end den gode samvittighed, hvor vi roser os selv for en eller anden indstilling eller handling.

Men ligegyldigt om samvittigheden er god eller dårlig, så er det karakteristisk, at vi altid henviser til den, som vores egen personlige besiddelse. Samvittigheden er derfor på den ene side altid min. 
Men Luther og Kierkegaard mener alligevel ikke, at samvittighedens rum er hermetisk lukket omkring det enkelte menneske. I samvittigheden forholder vi os nok til os selv som "hin Enkelte", altså som en konkret, unik person, der reflekterer over egne indstillinger og handlinger. Men i og med vi forholder os til os selv i samvittigheden, forholder vi os samtidig til en fælles etisk norm. En norm, vi ikke selv har opfundet, men som taler til os, og i os og som gør, at mine samvittighedskvaler også er forståelige for en anden. Samvittighedens rum er derfor nok i og for den enkelte, men det er et rum, der så at sige gentages i andres bevidsthed og derfor er samvittighedsspørgsmål alment forståelige.

Og det er derfor, at Kierkegaard, inspireret af Luther, ikke mener, at samvittighedens stemme er min egen stemme. Han mener derimod at samvittigheden taler med Guds stemme, hvilket harmonerer fint med både hans og Luthers opfattelse af Gud som et forhold, det enkelte menneske finder i sig selv. I To taler ved Altergangen om Fredagen lyder det:

Thi medens det kun er altfor sandt, hvad Luther siger, at ethvert Menneske har hos sig en Prædikant, han spiser med ham, drikker med ham, vaager med ham, sover med ham, kort er altid om ham, altid med ham, hvor han saa er, hvad han saa end foretager sig, en Prædikant, der hedder Kjød og Blod, Lyster og Lidenskaber, Vaner og Tilbøieligheder: saa er det ogsaa vist, at der i ethvert Menneskes Inderste er en Medvider, der lige saa nøiagtigt er med overalt, Samvittigheden (SKS 12, 297). ${ }^{3}$

Kierkegaard betoner igen og igen i forfatterskabet, at selvforholdet og gudsforholdet er så forviklede, at man ikke kan tænke det ene uden det andet: "Den sande Autodidakt han er netop i samme Grad Theodidakt", siges det i Begrebet Angest (SKS 4,460), idet der samtidig henvises tilbage til Enten-Eller, hvor en anden af Kierkegaards pseudonyme forfattere har sagt det samme (SKS 3,257).

Det latinske ord conscientia betyder både "at vide med" og "samvittighed". Og hvem er det, man ved noget sammen med i samvittigheden? Det mest nærliggende svar ville være, at man ved noget sammen

3. Og videre lyder samme sted: "Det kan maaskee lykkes et Menneske at skjule sine Synder for Verden, han kan maaskee daarligen glæde sig ved, at det lykkes ham, eller dog, lidt sandere, tilstaae, at det er sørgelig Svaghed og Feighed, at han ikke har Mod til at blive aabenbar: men for sig selv kan et Menneske ikke skjule sine Synder. Det er umuligt; thi den Synd, der ogsaa var ganske ubetinget skjult for En selv, vilde jo ikke være Synd, saa lidet som hvis den var skjult for Gud, hvilket heller ikke er Tilfældet, da et Menneske, saasnart han er vidende om sig selv, og i Alt, hvori han er vidende om sig selv, tillige er vidende om Gud, og Gud vidende om ham" (SKS 12, 297). 
med sig selv. Kierkegaard er bestemt ikke afvisende overfor denne forståelse af samvittigheden som et refleksivt samtalerum, men han mener, belært af Luther, som nævnt ikke, at vi bare taler med os selv. Han siger derimod, at vores samvittighed kan betragtes som en samviden med Gud. Ja, i bogen Kjerlighedens Gjerninger fastslår Kierkegaard direkte: "thi at forholde sig til Gud, er netop at have Samvittighed", hvilket ligger i umiddelbar forlængelse af Luthers synspunkt. Og Kierkegaard fortsætter:

Derfor kunde et Menneske heller ikke have Noget paa sin Samvittighed, dersom Gud ikke var til, thi Forholdet mellem den Enkelte og Gud, Guds-Forholdet er Samvittigheden, og derfor er de saa forfærdeligt at have end det Mindste paa sin Samvittighed, fordi man strax har Guds uendelige Tyngde med (SKS 9, 147).

Hvis samvittighedsspørgsmål var spørgsmål, jeg blot afgjorde med mig selv, ville alle mine etiske beslutninger være subjektivistiske. Min etik kunne være en hel anden end din. Men det kan ikke passe, hvis det etiske er det almene og derfor universelt gældende, hvilket Kierkegaard mener og også tager Luther til indtægt for, når denne taler om, at loven, den naturlige lov, er indskrevet også i hedningernes hjerte.

Nok handler vi altid som selvstændige subjekter, når vi handler etisk, men i og med at Kierkegaard og Luther mener, at samvittigheden betegner en samviden med Gud, så åbner det op for adgangen til et større fælles etisk rum: I samvittigheden ved man ikke noget alene, men sammen med andre. Det er dét, henvisningen til Gud skal sikre. Og derfor kan man selv og ens næste stole på samvittigheden. Det reflekterer Kierkegaard over i en sen journaloptegnelse: "Det er forøvrigt smukt i det tydske Sprog, at Gewissen betyder det Visse og tillige Samvittighed. Samvittighed det er den egentlig Vished. Skade, at vi ikke har det Ord paa Dansk" (SKS 22,192).

\section{Den spidsfindige samvittighed}

I samvittigheden er det altså så at sige Gud, der taler med mig, når jeg taler med mig selv, hvis man spørger Luther og Kierkegaard. I samvittigheden er Gud det forhold, at jeg ikke selv er herre over min samvittighed. Den melder sig af sig selv. Henvender sig på ubelejlige tidspunkter. Taler til mig, når jeg egentlig helst ville være den foruden. Men alligevel understreger Kierkegaard i Opbyggelige Taler $i$ 
forskjellig Aand at samvittigheden ikke er en "Trediemand": "thi Du og Samvittigheden er Eet, den veed Alt hvad Du veed, og den veed, at Du veed det" (SKS 8, 230).

På den ene side taler jeg med mig selv, når jeg taler med min samvittighed, men på den anden side er samvittigheden ikke bare min egen stemme, for jeg kan faktisk forsøge at overhøre eller overdøve dens stemme. Stadig i Opbyggelige Taler i forskjellig Aand lyder det:

Her i Timeligheden vil allerede Samvittigheden gjøre Hver især til den Enkelte; men her i Timeligheden, i Uroen, i Støien, i Trængslen, i Mængden, i Udflugternes Urskov, ak, ja her skeer jo enddog det Forfærdelige, at En ganske overdøver sin Samvittighed - sin Samvittighed, thi af med den bliver han ikke, den bliver hans eller rettere han er dens (SKS 8, 228).

Og det er netop fordi vi som oftest forsøger at negligere samvittighedens stemme, at vi kender den dårlige og den ængstede samvittighed bedre end den gode. For tit bliver samvittighedens stemme "blot en Stemme med blandt mange andre, og da gaaer det saa let Samvittighedens eenlige Stemme, som ellers den eenlige, at den bliver overstemt - ved Stemmefleerheden" (SKS 8, 228).

I stedet for at lytte til samvittighedens stemme, lytter vi til, hvad flertallet siger. For flertallet har vel ret? Vi gør som de andre og gemmer os derved i mængden. Og når ansvaret skal placeres, så henviser vi til, at vi blot har gjort som enhver anden ville have gjort.

Men den demokratiske flertalsbeslutning har for Kierkegaard og Luther intet at gøre på samvittighedens domæne. Her taler den enkelte med sig selv og samtidig med Gud. Da den 37-årige Luther under mødet med den da 21-årige Kejser Karl V på rigsdagen i Worms afviser at tilbagekalde sine anklager mod pavekirken og sin udlægning af den kristne budskab henviser han netop til sin samvittighed som bundet til Gud: "Så længe min samvittighed er bundet af Guds ord, kan og vil jeg ikke kalde noget tilbage, eftersom det ville være usikkert og true saligheden at handle mod min samvittighed. Gud hjælpe mig. Amen". ${ }^{4}$

Selv om denne indre stemme lyder i enhver og som sådan danner grundlaget for et alment etisk rum, er det ikke det almene, men den enkeltes personlige ansvarlighed over for det almene, ville Kierkegaard sige, over for næsten ville Luther sige, der er kernen i samvittigheden.

4. Citeret efter Heinz Schilling, Martin Luther. Rebel i en opbudstid, (København: Kristeligt Dagblads Forlag [2012] 2017), 209. 
Når man forsøger at overhøre samvittighedens stemme kaldes det i Afsluttende uvidenskabeligt Efterskrift at have en "spidsfindig Samvittighed", hvilket desværre er ganske almindeligt, mens pseudonymet Anti-Climacus, forfatteren til Efterskriften, omvendt kun sjældent mener, at have kunnet iagttage "et egentligt samvittighedsløst Menneske" (SKS 7, 549). Det skyldes formentlig, at radikal samvittighedsløshed faktisk er et patologiske fænomen, som vi i dag ville kalde psykopati, hvorfor det heldigvis ikke er så ofte set hverken på Luthers og Kierkegaards tid eller i dag. Psykopati er netop ikke en sindssygdom, men en art brist i selve personligheden. Med Luther og Kierkegaard kunne man kalde det en brist i ens forhold til sin samvittighed.

Men det er jo ikke alle tænkere efter Luther, der som Kierkegaard deler hans positive syn på samvittigheden og fortolkningen af dens rolle.

\section{En selvopfunden samvittighed}

Friedrich Nietzsche kritiserede i Zur Genealogie der Moral fra 1887 den kristne moral for at være en slavemoral. Med det mente han, at værdier som barmhjertighed, medlidenhed og ydmyghed var værdier, som den svage havde opfundet, fordi han eller hun ikke selv havde styrke nok til at leve efter værdier som stolthed, upåvirkelighed, og mod. Udgangspunktet for Nietzsche er således, at alle moralske værdier er en menneskelig oprindelse. Og han mener, at den kristne moral udspringer af et ressentiment; et fortrængt had og en camoufleret hævngerrighed, som de svage, kaldet slaverne, har til de stærke, kaldet herrerne eller "overmennesket", som er det menneske, der tør sætter sine egne værdier.

Det er påstanden om Guds død, der får Nietzsche til at fastslå, at der ikke gives evige eller absolutte værdier og at alle former for moral derfor bygger på en vilkårlige fastsættelse af værdier ud fra rent subjektive perspektiver. Og det er på baggrund af denne opfattelse at Nietzsche i 1970 'erne og 1980'erne bliver inspirator for postmodernismen og den individualisme og selvoptagethed, jeg nævnte tidligere. Hans teori om perspektivet, om at det er afgørende hvilken optik man ser et begreb eller en værdi i, blev netop benyttet i opgøret med "De store fortællinger" og aflivningen af tanken om, at der skulle findes en Sandhed med stort "S".

For Nietzsche er sandhed altid bestemt af den, der ser, altså af perspektivet. Der er ingen værdier, der er værdifulde i sig selv og det er 
derfor han i Götzendämmerung fra 1888 kan slå til lyd for, at alle værdier må omvurderes.

Luther og Kierkegaard mener ikke, at hverken sandheden eller værdierne er rent subjektivistiske. Men den og de er heller ikke objektive størrelser. Som nævnt er den personlige tilegnelse, det lille "for dig" i højsædet hos både Luther og Kierkegaard. Og det skyldes netop, at de anser samvittigheden for at være et tidløst fællesetisk rum, der sætter den personlige ansvarlighed i centrum.

Samvittigheden rummer således forstået en universel etik, noget alment, der gennem det enkelte menneskes samråd med sin samvittighed skal gøres til hans eller hendes moral og dermed hans eller hendes personlige ansvar. I samtalen med samvittigheden opretholdes selve et menneskes menneskelighed. For Nietzsche er det omvendt sådan, at det er den moral, vi selv har valgt, der skaber vores samvittighed. $\mathrm{Og}$ da det er os selv, der ifølge Nietzsche har skabt moralen, er det også os selv, der er ophav til vores dårlige samvittighed. For Nietzsche er samvittigheden således ikke Guds stemme, men en social mekanisme til mental undertrykkelse. I samvittigheden lukker mennesket sig selv inde i et selvskabt fængsel og tør ikke følge sine instinkter. I samvittigheden bliver lysten en last.

Det "Overmenneske" Nietzsche taler om, er det menneske, der tør sætte sine egne værdier. At værdierne har mistet deres grundlag behøver derfor ikke at føre til svaghed, men til en form for nihilistisk styrke: Når Gud ikke længere er garant' for mening og sammenhæng må vi selv skabe den.

For Nietzsche er samvittigheden således en selvpåført sygedom. For Luther og Kierkegaard er det lige omvendt. Det er en sygdom ikke at ville lytte til sin samvittighed. Problemet opstår, når vi forsøger at erstatte vores samvittighed med et nyt, selvkonstrueret system: Kierkegaard siger i en journaloptegnelse fra 1849: "det Mange, ja de Fleste kalde Samvittighed er slet ikke Samvittighed, men vapeurs [dampe], Opstød fra Maven, Gavtyvestreger o: s: v: - en Ridefogeds Samvittighed" (SKS 21, 230).

\section{Det Sædelige}

Man kunne også sige, at de fleste mennesker forveksler samvittigheden med "det Sædelige”. "Det Sædelige” betegner for Kierkegaard det menneskeskabte og dermed foranderlige moralkodeks, der opstår til enhver tid og hele tiden er under udvikling. Det sædelige er bundet til tid og sted og ændrer sig således fra land til land og over tid. 
Ordet kommer af det tyske "Sittlichkeit", som Kierkegaard har overtaget fra G.W.F. Hegel (1770-1831). I Hegels Retsfilosofi betegner Sittlichkeit den tredje afdeling af etikken, der har at gøre med de konkrete pligter i forhold til livet i familien, samfundet og staten. Sådan benytter Kierkegaard også ordet "Sædelighed" eller "Det Sædelige". For Kierkegaard betegner "Det Sædelige" det borgerlige livs samkvemsformer i alle dets afskygninger. Det sædelige, både som skik og brug og som lovgivning, er garanten for lov og orden i ethvert samfund og kan ændre sig fra samfund til samfund. "Det Sædelige" er menneskeskabt - socialt konstrueret - og derfor selvfølgelig foranderligt. Det svarer til Luthers syn på fx alle de konkrete, kausuistiske love i Det Gamle Testamente.

"Det Sædelige" er derfor ikke universelt og almengyldigt, men partikulært og relativt. Det er det sædelige, der afstikker reglerne for, hvordan vi lever sammen i et givent samfund. Det er der bestemt ikke noget galt med, men det er Kierkegaards pointe, at det sædelige kan og skal afgøres uden om samvittigheden.

Det etiske, der bor i samvittigheden er derimod universelt. Det gælder uafhængigt af tid og sted, af nationalitet, religiøsitet og seksualitet. Derfor kalder Kierkegaard det etiske for det almene og Luther taler om loven, der er indskrevet i vores hjerter.

Menneskerettighederne og de erklæringer, der fastslår dem, tilhører fx det sædeliges område. De er så at sige et udefrakommende tillæg til samvittigheden, der er blevet vedtaget på et givent tidspunkt i historien. En vedtagelse, der var blevet nødvendigt, fordi vi på trods af samvittigheden behandlede andre mennesker som undermennesker, som slaver. Værdierne, der kom frem under den franske revolution (1789) og siden FNs erklæring om menneskerettighederne i 1948 hylder og fastsætter en række værdier som frihed, lighed og broderskab, fordi historien har vist, at magthavere negligerede disse værdier til fordel for magten. Men i samvittigheden er der ingen på forhånd afgjorte værdier. Her afhænger det af, hvordan man forholder sig til sig selv og det man gør.

Hvad så med næstekærligheden? Her deler vandene sig. For hverken Luther eller Kierkegaard udspringer næstekærligheden spontant af samvittighedsforholdet. Næstekærligheden er en specifik kristen værdi, et bud, ja, et påbud, som nok nu mange steder i den protestantiske verden opfattes som så selvfølgelig, at vi tror, at den ligger som en del af vores samvittighed. Men det gør den ikke ifølge Luther og Kierkegaard: Men det er i vores samvittighed, vi skal beslutte os for, hvorvidt vi skal gøre det ene eller det andet, hvis vi vil handle næstekærligt. 
I samvittigheden forholder vi os til os selv, til hvad vi gør og til hvad vi kunne have gjort anderledes. Og om end samvittigheden udgør dette fælles etiske rum, hvor vores beslutninger kan gøres alment genkendelige og forståelige af andre, så er samvittigheden samtidig det sted, hvor vi dømmes syndige. Og denne dom ængster naturligvis samvittigheden.

\section{Den ængstede samvittighed}

Hverken Kierkegaard eller Luther opfatter samvittigheden som en passiv instans i subjektet. Vi er ikke bare samvittighedsfulde fordi vi har en samvittighed. Her spiller synden - uvilligheden til at gøre det gode, vi ved, er det gode, ind. Vi skal således gøre noget, for at blive samvittighedsfulde: "Thi hvad er det at være og at ville være den Enkelte? Det er at have og at ville have Samvittighed", siger Kierkegaard i den posthumt udgivne Synspunkt for min Forfatter-Virksombed (SKS 16, 149).

Nok er samvittigheden almen, men den er altid personlig. Man taler som nævnt altid om sin samvittighed. At følge sin samvittighed er derfor at oversætte sig selv og sine handlinger fra det enkelte til det almene. Samvittigheden har at gøre med det enkelte menneskes etiske enkelthed. Hvad han eller hun beslutter sig for at gøre. Om sig selv siger Kierkegaard i en sen journaloptegnelse:

Man beskylder mig for at jeg foranlediger unge Mennesker til at slaae sig til Ro paa deres Subjektivitet. Maaskee, et Øieblik. Men hvorledes skulde det være muligt at faae alle disse Objektivitetens Blendværker bort som Publikum o: s: v: uden ved at faae Enkelthedens Kategorie frem. Man har under Skin af Objektivitet villet aldeles offre Individualiteterne. Derom dreier Sagen sig (SKS 20,88).

Det er gennem vores forhold til os selv, gennem vores subjektivitet, som vi ikke skylder os selv og derfor i ét hermed gennem vores forhold til Gud i samvittigheden, at vi hver især bliver "hin Enkelte". Ikke, slet ikke, ved at negligere forholdet til fælleskabet eller næsten som er samvittighedens hele sigte for Luther og Kierkegaard. Det er samvittigheden, der kan gøre mig til min næstes næste. I en journaloptegnelse siger Kierkegaard: "I Samvittigheden har Gud faaet Øie paa mig, og nu er det gjort mig umuligt, at glemme at dette $\varnothing_{i e}$ seer mig. Det at Gud saae paa mig gjorde at jeg maatte see og maa see paa Gud" (SKS 20, 160). For Kierkegaard og for Luther, vil jeg mene, er 
der tale om, at Guds øje er det øje, jeg i samvittigheden ser på mig selv med. Eller sagt med andre ord: Det er ikke op til mig at afgøre, om jeg har god eller dårlig samvittighed. Det sørger samvittigheden selv for at lade mig vide.

Samvittigheden er således forstået en udvidelse, et tillæg til mennesket, der ligger ud over både dets psykiske og fysiske formåen og fremtoning. Samvittigheden er så at sige en usynlig hat, der gør et menneske etisk synligt overfor dets næste. I en journaloptegnelse lyder det

\footnotetext{
Man taler om, at ethvert Menneske har Samvittighed, og forudsætter det: og dog er der ingen Færdighed (hverken en legemlig fx at dandse, synge o: s: v: eller en aandelig fx at tænke og Deslige) der fordre en saa langvarig og saa anstrengende Skole som inden et Menneske egentlig kan siges at have Samvittighed (SKS 21, 229).
}

Tillad mig her til slut at belyse samvittighedens afgørende og blivende betydning med følgende eksempel: I bogen Eichmann i Jerusalem der bærer den sigende undertitel en rapport om ondskabens banalitet, der udkom første gang på engelsk i 1963, skelner den tyske filosof Hannah Arendt (1906-1975) mellem den radikale og den banale ondskab. ${ }^{5}$

Som korrespondent for The New Yorker fulgte hun den israelske retssag mod den jævnaldrende tyske SS-officer Adolf Eichmann (1906-1962) i begyndelsen af 1960'erne. Eichmann var under krigen ansvarlig for deportationen af millioner af jøder til de nazistiske kz-lejre og blev først fundet i Argentina i 1960 og da bragt for en domstol i Jerusalem. I 1962 blev han hængt for forbrydelser mod menneskeheden.

Under hele retssagen fastholdt Eichmann, at han ikke havde handlet ud fra et personligt had til jøder, men at han blot havde adlydt ordrer. Han var intet bestialsk monster, men blot en medløber, ja, faktisk en pligtopfyldende embedsmand.

Det er dette, der får Arendt til at beskrive hans ondskab som banal. Den banale ondskab består $i$, at lade være med at stille kritiske spørgsmål til det system eller samfund, man tjener. Den banale ondskab består i at overhøre samvittighedens stemme, ikke som en individuel stemme, men som talsmand for et fællesetisk rum, der både står over de givne magthavere og den almindelige mening i samfundet - altså over det sædelige.

5. Hannah Arendt, Eichmann i Jerusalem en rapport om ondskabens banalitet (København: Gyldendal 2008). 
Samvittigheden bliver derfor et nøglebegreb hos Hannah Arendt og selv om hun kalder Eichmanns ondskab for banal fratager det ham bestemt ikke skylden. For han havde jo friheden til at sige nej og muligheden af at lytte til samvittighedens stemme.

Arendts pointe er derimod, at den banale ondskab, der kendetegner Eichmann, er vi desværre alle sammen er i stand til at udføre. Ondskaben er ikke dyb og dæmonisk. Der er ikke tale om en uregerlig kraft forbeholdt psykopater eller sadister. Ondskaben er helt banal og viser sig i enhver af os, hvis vi ikke lytter til samvittighedens stemme. Det var det Luther så og Kierkegaard så, at Luther havde set. Luther mente ikke blot, at pavekirken misfortolkede evangeliet, men også at den udøvede et magtmisbrug, der fratog det enkelte menneske den personlige ansvarlighed ved at negligere samvittighedens stemme $\mathrm{i}$ den enkelte og kræve blind lydighed overfor kirken og traditionen.

Problemet for Eichmann var, kunne man sige, at han netop ikke havde en ængstet samvittighed. Det er ellers netop Luthers pointe, at det har ethvert menneske. Det var netop denne omsiggribende ængstede samvittighed, der fik ham til at tøve med at afskaffe skriftemålet, da han reducerede sakramenterne fra 7 til 2 i den protestantiske kirke. Ja, man kunne faktisk vove den påstand, at det er den ængstede samvittighed, der udgør hele grundlaget for den protestantisek bevægelse Luther blev ophav til. Det er ganske enkelt grundet menneskets ængstede samvittighed, at Gud er blevet menneske. Og heri kan Kierkegaard og Luther sagtens enes. I en journaloptegnelse fra december 1846 skriver Kierkegaard: "Det er Ypperligt, det ene Fornødne og det ene Forklarende hvad Luther siger: at hele denne Lære (om Forsoningen, og i Grunden hele Xstd. [kristendommen]) maa henføres til den ængstede Samvittigheds Kamp” (SKS 20,69).

Denne lille artikel kan i sagens natur ikke levere en udtømmende beskrivelse af Kierkegaard forhold til Luther filosofisk set. Jeg har dels valgt at stille skarpt på forholdet mellem fornuften og troen, som bestandigt vil volder teologien problemer, og som Kierkegaard og Luther som vist har hvert deres bud på. Jeg har tillige forsøgt at vise, at Kierkegaard er stærkt præget af Luther både når det gælder det enkelte menneskes personlige tilegnelse af det kristne budskab og synet på samvittighedens afgørende rolle for et menneskeværdigt liv. 